\title{
sciendo
}

\section{The Influence of Critical Factors on Business Model at a Smart Factory: A Case Study}

\author{
Andrej Jerman \\ Ljubljanski potniški promet, d.o.o., Slovenia \\ Ivan Erenda \\ TPV, Slovenia \\ Andrej Bertoncelj \\ University of Primorska, Faculty of management, Koper, Slovenia
}

\section{Abstract}

Background: The crucial elements of a smart factory, employees, machines, and products, have an important effect on current business models. Objectives: The main aim of our study is to present a case study of the impact of Industry 4.0 on the business model in a smart factory. The paper discusses the changes of business models of the organisation and determines critical factors that influence the business models in a knowledge society. Methods/Approach: Our sample included managers, from the company TPV, who are in charge of implementing a digital business model, and who are the most knowledgeable informants on the topic of our study. Data was obtained from, most widely used method for data collection in qualitative research, semistructured interviews with managers. Content analysis was conducted for the purpose of our study. Results: Results of our study show that the major change will be that machines will have a "mind" of their own, whose main goal will be to work in production, and the role of employees will be primarily in expressing their creativity, carrying out urgent interventions and performing custody of processes. The key critical factors influencing business models in a smart factory are top management and leadership orientations, motivation of employees, collective wisdom, creativity and innovations. Conclusions: The study represents useful guidelines for strategic management of innovative companies in the earliest stages of the process of decision-making process.

Keywords: Industry 4.0, Smart factory, business model, critical factors, TPV case study JEL classification: M40

Paper type: Research article

Received: Feb 25, 2018

Accepted: Apr 07, 2018

Citation: Jerman, A., Eranda, I., Bertoncelj, A., (2019), "The Influence of Critical Factors on Business Model at a Smart Factory: A Case Study," Business Systems Research, Vol. 10 No. 1, pp. 42-52.

DOI: 10.2478/bsrj-2019-0004

\section{Introduction}

Organisations are open systems, which are affected by the external (e.g. the customers' and suppliers' requirements and market conditions) and internal 
environment (eg. owners', managers' and employees' attitudes and needs) (Dominici and Roblek, 2016). Due to globalization, organisations are exposed to rapid changes, which have great impact on product operations, development, and the organisation success (Teece, 2014). New business models can help organisations to reach the success, which can be done by creating positive or reducing negative external effects for the organisation (Schaltegger, Ludeke-Freund and Hansen, 2016).

In addition to this, knowledge represents the leading and basic source of competitive advantage for an organisation (Schultze, 2002). It is an economic growth vehicle for in the 21 st century knowledge-based economy. Because of new business logic and knowledge integration, also presumes that "the rate of economic growth in the knowledge-based economy depends on services or products" (Roblek et al., 2014).

The purpose of our study is to focus on the impact of Industry 4.0 on business models in a smart factory. The paper discusses the changes occurring in business models for the purpose of achieving digitalization, sustaining competitive advantages of the organisation and determining critical factors affecting the business models in a knowledge society. Transformation of the traditional business model to a digital business model is happening for the goal of delivering new values to employees and customers and the ability to compete more effectively in a digital economy (Solis, 2017). Digital business strategies create complex and dynamic ecosystems of the company, so as to enable its growth and innovation (lansiti and Lakhani, 2014).

Hence, the main purpose of this paper is to answer the following research questions:

- RQ1: How will the business model of a smart company change?

- RQ2: What are the critical factors affecting the business models in a smart factory?

The structure of our paper is as follows: The paper starts with the theoretical background of Industry 4.0 and smart factories. The second section of the paper presents definitions and the concept of business models, as have been given by different authors. The third section presents literature review on critical factors in business models. The forth section presents methodology. In next section, the research results have been presented and discussed. Finally, conclusions, including limitations and orientations for future researchers, have been drawn.

\section{Theoretical framework}

\section{Industry 4.0 and the concept of a Smart Factory}

In the second decade of the 21st century, a third industrial revolution emerges, bringing new technological developments that involve high-end robotics. This does not only affect the migration of jobs, but also the loss of jobs (Lasi et al., 2014). In Germany, a new view of economic policy was developed in 201 1, called Industry 4.0, which basis are high technology strategies (Mosconi, 2014). The concept is based on "concepts and technologies that include Cyber-Physical Systems (CPS), Internet of Things (loT) and Internet of Services - (IoS)" (Roblek, Erenda and Meško, 2018). Industry 4.0 depends on continuous communications between machines and people and among the machines themselves over the Internet, which enables continuous exchange of information and interaction (Roblek, Meško and Krapež 2016).

The positive side of Industry 4.0 is the creation of value, which includes both an increase in effectiveness and the development of contemporary business models. Moreover, Industry 4.0 introduces new possibilities that will likely disrupt the traditional business models. However, it should be noted that technological changes have an effect on employment, which can be positive and negative. The challenge in smart 
companies will be the reconstructions of jobs, from skilled to smart workers (Kane et al., 2015). Increasing productivity achieved using smart technologies can support to provide new jobs and increase consumer demand with additional income (compensatory effect), but, on the other side, the use of advance technologies and processes can also have redundancy effects on jobs. There is concern that Industry 4.0 will lead to long-term unemployment caused by advancing technology (Hungerland et al., 2015). Job profiles in many jobs will change, which means that important measures will be needed to transform and adapt the field of employee education and development.

The smart factory, as defined by Wang and colleagues (2016) is "a cyber-physical system that implements flexible and agile production and integrates physical objects such as machines, conveyers, and products with information systems". A key characteristic of Industry 4.0 is smart factory, which "is characterized by a selforganized multi-agent system assisted with big data-based feedback and coordination" (Wang et al., 2016). An important feature of the smart factory is that its production "is equipped with sensors and autonomous systems and that machines and equipment have the ability to influence processes improvement through their own optimization and autonomous decision-making" (Roblek, Meško and Krapež 2016). The goal of a smart factory is to reach the connection of all smart devices, thus enabling their autonomous decision-making. This device connectivity, leading to a degree of connectivity that enables decision-making at the organization level, includes the Production Management System, the Energy Management System and the Integrated Information System (Gamarra, Guerro, and Montero 2016).

The transformation process of classic business models to smart - digital business models began in 2011. Smart connected technologies, artificial intelligence, innovations of technologies and concepts that enable the establishment of the Cyber-Physical Systems encourage the transformation of manufacturing and service organizations into smart factories (Russell and Norvig 2009)).

\section{Business model}

A business model is a category of organisation models, which describes business features. Different scholars offer different definitions and various perspectives on the business model; some of them are presented in the following text.

A business model is a concept, which explains how organizations operate and create values for stakeholders. Business models are composed of three areas, i.e. their application in information technology, strategic issues (performance, competitive advantage, and value creation), and technology management, and finally productservice innovation (Marin, Boanta, Hadar and Badea, 2015). A business model is also defined as a conceptual tool, which is which elements are set of concepts, objects and their relationships, which expresses the business logic of a specific organisation (Michelini and Fiorentino, 2012). A business model includes core value dimensions: value preposition, value creation, value creation infrastructure, value creation conditions and value capture (Abdelkafi and Tauscher, 2016; Schaltegger, LudekeFreund and Hansen, 2016).

Functions of business models are to identify market segments, to formulate strategies, to articulate values, to define value chain structures, to describe the position of the organisation and to estimate cost structure and profit potential (Michelini and Fiorentino, 2012).

In order to develop new techniques, products, survices or organisational modes, modern organisations need innovative business models. For this reason, organisations can choose between two options, either to introduce brand new business models or 
transform the existing business models (Sommer, 2012; Schaltegger, Ludeke-Freund and Hansen, 2016).

\section{Literature review of critical factors influencing business models}

is important to know that when the external environment is dramatically changed, it is not possible to create value in the way organisations are used to (Capo, Brunetta and Boccardelli, 2014). For this reason, it is important to identify the critical factors affecting business models in knowledge society and encourage managers to be aware of them while planning for the future of the organisation. To answer research questions, a synthetic representation of literature has been reported. Firstly, we did a literature review, which shows factors influencing business models highlighted by different authors (see Table 1).

\section{Table 1}

The literature review of critical factors affecting business models

\begin{tabular}{|c|c|}
\hline Authors, year of publication & Critical factors \\
\hline $\begin{array}{l}\text { Marin, Boanta, Hadar and Badea, } \\
2015\end{array}$ & leadership and top management orientation \\
\hline Bernuy, 2011 & employee's motivation to share knowledge \\
\hline $\begin{array}{l}\text { Capo, Brunetta, and Boccardelli, } \\
2014\end{array}$ & innovations \\
\hline Michelini and Fiorentino, 2012 & creating shared value \\
\hline Vitari and David, 2017 & $\begin{array}{l}\text { intrinsing motivation of employee, long-term } \\
\text { objectives, collective wisdom }\end{array}$ \\
\hline Abdelkafi and Tauscher, 2016 & natural environment \\
\hline McAdam and McCreedy, 1999 & intellectual capital \\
\hline Bernuy, 2011 & employees sharing knowledge \\
\hline $\begin{array}{l}\text { Schaltegger, Ludeke-Freund and } \\
\text { Hansen, } 2016\end{array}$ & $\begin{array}{l}\text { Processes of business model: variation (innovation), } \\
\text { selection (elimination unsustainable business models) } \\
\text { and retention }\end{array}$ \\
\hline Roome and Louche, 2016 & $\begin{array}{l}\text { subprocesses of business model: identifying, } \\
\text { translating, embedding, sharing }\end{array}$ \\
\hline Dinu, 2017 & $\begin{array}{l}\text { communication among stakeholders, knowledge } \\
\text { sharing }\end{array}$ \\
\hline
\end{tabular}

Source: Authors' work

Business models are a "living organism" influenced by different factors, such as leadership and top management orientation (Marin, Boanta, Hadar and Badea, 2015). It is utmost important to find advanced business models and take into account digitalization and other important impacts of Industry 4.0. Business models should also be effectively communicated among stakeholders and interpreted correctly by the person who creates them (Pelantova and Šlaichova, 2017). The orientation towards innovations is essential to provide sustainable business models (Capo, Brunetta, and Boccardelli, 2014). Knowledge sharing is another important factor influencing business models, it is essential to encourage employees to be prepared to share knowledge. However, in most cases, employees are not prepared to share them, because they think that keeping their knowledge private will keep their job secure (Bernuy, 2011).

Internet revolution has made business models popular. They affect business in many ways, for example the way company generate revenue, way of understanding the core logic of any company etc. Digital technologies transforming existing business models, the Internet-of-Things stand to change every company, from the automotive industry to manufacturing. Due to constant changes in business environment, business models need to be sustainable, so they can adapt easily. When conditions change, 
they must be feasible to function effectively (Haaker, de Reuver and Bouwman, 2018). Intending to accomplish the main aim of our study, we examined the changes of business model and determined critical factors that influence on the transformation from traditional to digital business model at a smart factory in order to attain competitive advantage of the organisation.

\section{Methodology}

\section{Sample}

To gain insight into the critical factors that influence business models, we studied the innovative supplier TPV from the automotive industry. We were interested in TPV because the automotive industry has always been a field of most rapid transformations and fastest pace of technological development. A case-study strategy was employed (Yin, 2014) in order to provide valuable insights in the field of management (Eisenhardt and Graebner, 2007). The case study is an appropriate approach that allows for a thorough analysis of the phenomena and issues that compose our research interest. The positive side of this approach is seen mainly in depth and integrity, which enables the researcher to be more involved in the research process itself and to see the whole picture of the phenomenon under consideration (Noor, 2008).

Our sample included managers from TPV in charge of implementing a digital business model, which also include the prototype and industrial conceptualisation of the smart factory. They are highly engaged and competent in the field of automatization, robotisation, digitalization and organizational management. As such they represent the most knowledgeable informants on the topic of our study. TPV was established in 1989 as part of the former IMV ("Industrija motornih vozil"), which was broken into Revoz, Adria Caravan, TPV and TADO. The name originates from their initial specialization in military jeep development, even though the vehicle was never constructed due to the downfall of Yugoslavia. At that time, the expectations for the company were grim, but nowadays, their components are installed in all major-brand cars on the market. TPV develops its solutions based on many years of experience from its own production, knowledge in the field of the latest technologies, innovation and networking with development partners.

\section{Method}

The paradigm used in the study is qualitative, which enables us in-depth studies of realworld settings and captures the contextual richness and meaningful descriptions. The characteristic of a qualitative paradigm is that the results are based on the subject's subjective judgment. Therefore, the repeated problem mentioned in the qualitative paradigm is a problem of generalizing the data, which means that data obtained on one case cannot be generalized (Myers, 2009). Another important characteristic of qualitative research is that in using it we do not renounce, and we do not allow it to be merely a methodological mechanical determination of isolated facts. The obtained data in the qualitative analysis are processed and analysed in word mode, without the use of measurement procedures (Easterby Smith, Thorpe and Lowe, 2007, pp. 85-130). The qualitative techniques used in the qualitative paradigm are interpretative techniques that help us to describe, decode, and translate the meaning of phenomena in the social world (Dimovski et al., 2008).

Intending to accomplish the purpose of our study, we conducted content analysis, in order to gain new knowledge on business models based on primary data. Content analysis is a research method, more specifically an empirically grounded method, 
mostly used in the social sciences. As a method, it is concerned with meanings, references and intentions. Content analysis was developed as a methodology in order to "plan, execute, communicate, reproduce, and critically evaluate the particular results" (Krippendorff, 2013). For data analysing we used the Atlas.ti program, analytical and visualization tool, which helped us to see new views on the studied data or assumed relations between categories in attributing the interpretation of a research phenomenon (Lamut and Macur 2012).

\section{Data collection}

We collected data with the use of an in-depth semi-structured interview as described by Easterby Smith, Thorpe and Lowe (2007). Interviews are one of the major data collection methods, where the most common division is structured. The socioconstructionist perspective emerges (Easterby-Smith, Thorpe and Lowe, 2007).

Interviews have a strictly defined protocol. The questions are open-ended and follow a certain previous framework. The interview included an accompanying speech in which we clarified the purpose and objectives of the research, gave all necessary instructions and assured anonymity. The interviews were taped using a desk microphone and were transcribed.

The interviews containing the following main questions: How do you define a smart factory? When do you plan to finish the project of transformation to smart factory? What obstacles do you see in your company for transition a transition from a traditional to digital business model? What are the benefits of new, digital business model? What, in your opinion, will change the most? Which elements of business model will include just minor changes? Which are critical factors influence transitions from a traditional to digital business model?

A single interview lasted about 60 minutes. We recorded them to facilitate the refreshment of the memory. After that, we have consistently entered the content of the responses into the encoding table

\section{Results and discussion}

In the mid-1980s, the transformation of the "traditional heavy industry" into a technology-driven development economy began (Alavi and Leidner 2001). Technological transformation processes have encouraged the creation of a knowledge society that has a significant impact on organizational change in terms of transforming business models (Ave, Biesdorf and Henke 2016). For the purpose of study, we set two research questions: (i) RQ1: How will the business model of a smart company change?, and (ii) RQ2: Which are the critical factors that influence the business models in a smart factory?

We compressed many words from texts into content categories based on rules of coding. More specifically, all texts from transcripts interviews were coded. Coding was used (Creswell, 2003).

All of the text, relevant for the content analysis, were examined by researchers (authors of this paper) according to the following three steps (Atlasti.com): (i) preparing the literature, (ii) going through the literature, and (iii) preparing the written review (Figure 1).

We started qualitative analysis of material with the reduction and arrangements of data, followed by the organization and processing of data, which was an organized process of discovering the meaning of the text by selecting and combining data (terms and categories). Creating categories was the main feature of the analysis; it represents the basis from which we structure the acquired data. We completed the 
analytical process by searching for patterns of interactions between different categories.

Figure 1

Three steps of the content analysis

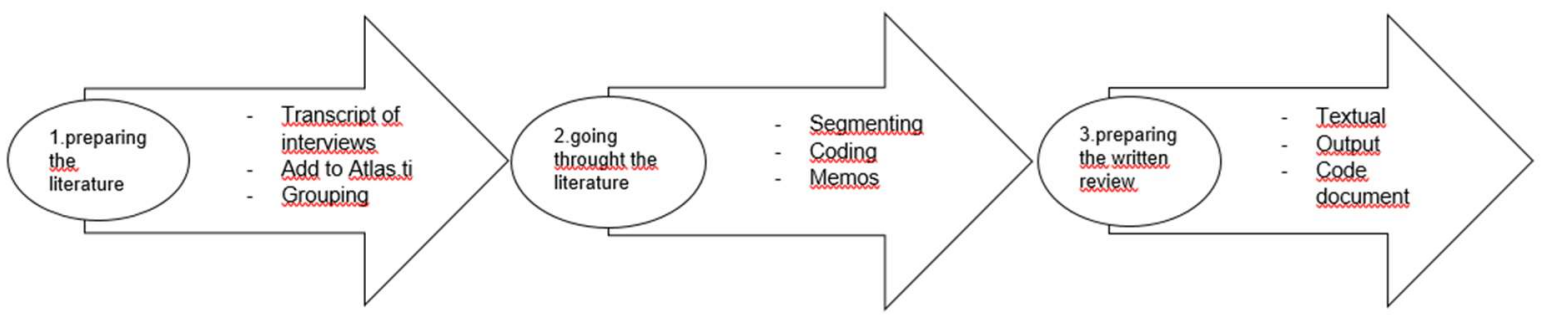

Source: Atlasti.com

Table 2 presents the main changes of the business model of a smart company. As we answer RQ1, three changes stood out as important, i.e. automatization, robotization, digitization as a one, integration of employees, machines and products as a second and redefinition of employees, machines and products roles in the factory as a third category. TPV has almost fully automatized production processes; they use primarily robots to replace human labour in processes, digitalization is present in control and tracking. Still all these concepts need improvement for TPV to become smart factory. Crucial challenge to change business model is integration of employees, machines and products and redefine their roles.

Table 2

Main changes of the business model of a smart company

\begin{tabular}{ll}
\hline Main changes (categories) & Sample quotation \\
automatization, robotization, digitization & "First I need to say that the main change will \\
be in automatization, robotization, \\
digitization..."
\end{tabular}

Source: Authors' work

The smart factory project of the TPV is planned to be realized in its prototype version by 2021 and by 2023 is expected to be full function operative. For the realization of the smart factory project, it will be necessary to change business model of the factory. Changes are introduced and will be introduced in all elements of the business model, as all elements are subject to the changes brought by Industry 4.0. Not all the changes represent a "revolution", i.e. radical changes, but the inclusion of all parts in the process of change is essential. The key change in the business model of smart factory will be reflected in automatization, robotization, digitization, in order to optimize processes. The TPV's main push factor for this is their corporate value of constant improvement through innovation. TPV motivates their employees to innovate through a reward 
system; they are focused mostly on internal innovation processes. Nevertheless, not all this represents the essence of the development of the smart factory, the essence of which is primarily the integration of employees, machines and products and the redefinition of roles in the factory. The role of employees will be primarily in expressing their creativity, carrying out urgent interventions (since it is assumed that artificial intelligence is not perfect now) and the performing custody of processes. The final product will be the same as it nowadays, of course, with improvements, with better quality characteristics. What is changing is the process leading to the final product.

The developed 4 categories that reflected the most frequently identified critical factors, when building new business model for a smart factory are shown in Table 3.

Table 3

The most important critical factors for building new business model

\begin{tabular}{|c|c|}
\hline Critical factors (categories) & Sample quotation \\
\hline Top management, leadership orientation & $\begin{array}{c}\text { "I think that the most important factor is } \\
\text { leadership orientation, especially orientation } \\
\text { of top management ..." }\end{array}$ \\
\hline Innovations, creativity & $\begin{array}{l}\text { "Business models of the future will consist } \\
\text { innovations and creativity as important } \\
\text { factors in business models..." }\end{array}$ \\
\hline Collective wisdom & $\begin{array}{c}\text { "An important factor for building the smart } \\
\text { factory is collective wisdom of all } \\
\text { employees..." }\end{array}$ \\
\hline Motivation of employee & $\begin{array}{c}\text { "Motivation of employees will be utmost } \\
\text { important factor..." }\end{array}$ \\
\hline
\end{tabular}

Source: Authors' work

The key critical factors that influence business models in a smart factory are top management and leadership orientation, motivation of employee, collective wisdom, creativity and innovations. It is not possible to optimize business models in a smart company without open-minded management, oriented towards innovations. Management should also motivate their employees and build a collective wisdom. Our results are similar to that of Vitari and David (2017), who found out that an emphasis should be given "to long-term objectives, intrinsic motivation of employee and collective wisdom" (Vitari and David, 2017). Capo, Brunetta and Boccardelli (2014), in their study, mentioned importance of innovations for sustainability for companies. Our results also show that creativity and orientation toward innovations are important factors of a new business model in the smart factory.

In our research we were focused on the process of reorganization, transformation of the business model of a classical factory into more intelligent, flexible and dynamic smart factory. An important feature of the smart factory is that its production is equipped with sensors in autonomous systems. Machines and equipment have the ability to influence the improvement of processes through their own optimization in autonomous decision-making (Roblek, Meško and Krapež 2016). The goal of a smart factory is to reach the connection of all smart devices, thus reaching an autonomous decision on them (Gamarra, Guerro and Montero 2016). This device connectivity, leading to the degree of connectivity that enables decision-making at the organization level, includes the Warehouse management system (WMS), Manufacturing execution system (MES), Business Intelligence (BI) and the Enterprise resource planning system (ERP). 


\section{Conclusion}

Development of industry is going towards smart factories; process management will take place in real time and consequently with maximum precision and efficiency. The goal of smart factories is to increase the efficiency of business operations. A core dynamic capability is ability of management to refine business models (Teece, 2007).

The purpose of our study was to gain insight about a studied phenomenon, i.e. business models of the future and to determined critical factors affecting the new, digital, business models in knowledge society. The contribution of this paper comes from a case study on new business model critical factors in the smart company.

From our findings, we can conclude that stakeholders of the organizations have to consider the the business environment complexity and the business processes changes. They need to be aware of the critical factors influencing business models and need to be ready for different changes in the complex environment. The businesssupport infrastructure needs to be developed due to initiated partnerships (Heesen, 2015).

The limitation that can be address in future research is that the research is done on only one case of a smart factory. The findings are based on meta-analysis and qualitative analysis of our case study. Future research should focus on deeper analysis of this subject matter and could include more case studies. Future studies can also include implementation, testing business, social and environmental benefits of a new business models with qualitative as well as quantitative data.

The application value of the study we mostly recognise as some useful guidelines for strategic management of innovative companies in the earliest stages of the process of decision-making process for conceptualization and implementation of the modules of smart factories. The recognised critical factors influencing business models should also represent the foundation for the pre-project activities, which because of its nature (long term activities) should start much earlier as all the other formal activities for planning and installing the smart company.

\section{References}

1. Abdelkafi, N., Tauscher, K. (2016), "Business models for sustainability from a system dynamic perspective", Organization \& Environment, Vol. 29, No. 1, pp. 74-96.

2. Alavi, M., Leidner, E. D. (2001), "Knowledge management and knowledge management systems: conceptual foundations and research issues", MIS Quarterly, Vol. 25, No. 1, pp. 107-136.

3. Ave, G., Biesdorf, S., Henke, N. (2016), "How healthcare system can become digitalhealth leaders", available at: http://www.mckinsey.com/industries/healthcare-systemsand-services/our-insights/how-healthcare-systems-can-become-digital-health-leaders (18 October 2017)

4. Bernuy, A. A. (2011), "Knowledge management and E-business", Revista Campus, Vol. 1, pp. 30-36.

5. Capo, F., Brunetta, F., Boccardelli, P. (2014), "Innovative business models in the pharmaceutical industry: A case on exploiting value networks to stay competitive", International Journal of Engineering Business Management, Vol. 6.

6. Creswell, J. K. (2003), Research design: qualitative, quantitative and mixed methods approaches, Sage, Thousand Oaks, CA.

7. Dimovski, V., Škerlavaj, M., Penger, S., Ghauri, P. N., Grønhaug, K. (2008), Poslovne raziskave/Business research, Pearson, Essex.

8. Dinu, V. (2017), "Total quality management - a way to manage organizations centred on quality", Amfiteatru Economic, Vol. 19, No. 11, pp. 936-938. 
9. Dominici, G., Roblek, V. (2016), "Complexity Theory for a New Managerial Paradigm: A Research Framework", in Vrdoljak Raguž, I., Podrug, N., Jelenc, L. (Eds.), Neostrategic Management, New York, NY: Springer, pp. 223-241.

10. Easterby Smith, M., Thorpe, R., Lowe, A. (2007), Management Research: An Introduction, Sage Publications, London.

11. Eisenhardt, K. M., Graebner, M. E. (2007), "Theory building from cases: Opportunities and challenges", Academy of Management Journal, Vol. 50, No. 1, pp. 25-32.

12. Gamarra, C., Guerrero, J. M., Montero, E. (2016), "A knowledge discovery in databases approach for industrial microgrid planning", Renewable and Sustainable Energy Reviews, Vol. 60, pp. 615-630.

13. Haaker, T., de Reuver, M., Bouwman, H. (2018), Do-it-Yourself: Business Model innovation: Hands-on Tools for your Business Makeover, TU Delft Library, Delft.

14. Heesen, B. (2015), Effective Strategy Execution: Improving Performance with Business Intelligence, Heidelberg, Springer.

15. Hungerland, F., Quitzau, J., Zuber, C., Ehrlich, L., Growitsch, C., Rische, M. C., Schlitte, F., Haß, H. J. (2015), The Digital Economy, Strategy 2030 - Wealth and Life in the Next Generation, Berenberg \& Hamburg institute of international economics, Hamburg.

16. Iansiti, M., Lakhani, K. R. (2014), "Digital ubiquity: How connections, sensors, and data are revolutionizing business", Harvard Business Review, Vol. 92, No. 11, pp. 91-99.

17. Kane, G. C., Palmer, D., Phillips, A. N., Kiron, D. (2015), "Is your business ready for digital future", MIT Sloan Management Review, Vol. 56, No. 4, pp. 37-44.

18. Krippendorff, K. (2013), Content Analysis: An Introduction to its Methodology, Sage publications, Thousand Oaks.

19. Lamut, U., Macur, M. (2012), Metodologija družboslovnega raziskovanja, Vega, Ljubljana.

20. Lasi, H., Fettke, P., Kemper, H. G., Feld, T., Hoffmann, M. (2014), "Industry 4.0", Business \& Information Systems Engineering, Vol. 6, No. 4, pp. 239-242.

21. Marin, A., Boanta, L., Hadar, A., Badea, D. (2015), "Business models and competitive advantage for technology transfer entities", The Romanian Review Precision Mechanics, Optics \& Mechatronics, Vol. 48, pp. 103-109.

22. McAdam, R., McCreedy, S. (1999), "A critical review of knowledge management models", The learning organization, Vol. 6, No. 3, pp. 91-101.

23. Michelini, L., Fiorentino, D. (2012), "New business models for creating shared value", Social Responsibility Journal, Vol. 8, No. 4, pp. 561-577.

24. Mosconi, F. (2014), The New European Industrial Policy: Global Competitiveness and the Manufacturing Renaissance, Routledge, London.

25. Myers, M. D. (2009), Qualitative research in business and management, Sage, London.

26. Noor, K. B. M. (2008), "Case study: A strategic research methodology", American journal of applied sciences, Vol. 5, No.11, pp. 1602-1604.

27. Pelantova, V., Šlaichova, E. (2017), "The Contribution to the Integration of Management Systems Oriented to the Sustainable and TQM", Amfiteatru Economic, Vol. 19, No. 11, pp. 951-965.

28. Roblek, V., Erenda, I., Meško, M. (2018), "The Challenges of Sustainable Business Development in the Post-Industrial Society in the First Half of the 21 st Century", in Leon, R. M. (Ed.), Managerial Strategies for Business Sustainability During Turbulent Times, Hershey, IGI Global, pp. 1-22.

29. Roblek, V., Meško M., Krapež, A. (2016), "A Complex View of Industry 4.0", Sage Open, Vol. 6, No. 2, pp. 1-12.

30. Roblek, V., Meško, M., Pejic Bach, M., Bertoncelj, A. (2014), "Impact of knowledge management on sustainable development in the innovative economy", in Basile, G. (Ed.), Systems Thinking for a Sustainable Economy: advancements in Economic and Managerial Theory and Practice, Business Systems Laboratory-2nd International Symposium, Rome: Universitas Mercatorum.

31. Roome, N., Louche, C. (2016), "Journeying toward business models for sustainability: A conceptual model found inside the black box of organisational transformation", Organization \& Environment, Vol. 29, No. 1, pp. 11-35. 
32. Russell, S. J., Norvig, P. (2009), Artificial Intelligence: A Modern Approach (3rd ed.), Prentice Hall, Upper Saddle River, New Jersey.

33. Schaltegger, S., Ludeke-Freund, F., Hansen, E. G. (2016), "Business models for sustainability: A co-evolutionary analysis of sustainable entrepreneurship, innovation, and transformation", Organization \& Environment, Vol. 29, No. 3, pp. 264-289.

34. Solis, B. (2017), "The definition of digital transformation", available at: http://www.briansolis.com/2017/01/definition-of-digital-transformation/ (20 January 2018).

35. Sommer, A. (2012), Managing green business model transformation, Springer, Heidelberg.

36. Schultze, U. (2002), "On knowledge work", in Holsapple, C. W. (Ed.), Handbook on Knowledge Management, Vol. 1., Springer, Berlin, pp. 43-58.

37. Teece, D. J. (2007), "Explicating dynamic capabilities: the nature and microfoundations of (sustainable) enterprise performance", Strategic Management Journal, Vol. 28, No.13, pp. 1319-1350.

38. Teece, D. J. (2014), "The foundations of enterprise performance: Dynamic and ordinary capabilities in an (economic) theory of firms", The Academy of Management Perspectives, Vol. 28, No.4, pp. 328-352.

39. Vitari, C., David, C. (2017), "Sustainable management models: innovating through Permaculture", Journal of Management Development, Vol. 36, No. 1, pp. 14-36.

40. Wang, S., Wan, J., Zhang, D., Li, D., Zhang, C. (2016), "Towards smart factory for industry 4.0: a self-organized multi-agent system with big data based feedback and coordination", Computer Networks, Vol. 101, pp. 158-168.

41. Yin, R. K. (2014), Case study research design and methods, Sage, Thousand Oaks, CA.

\section{About the authors}

Andrej Jerman is a doctoral student at the University of Primorska, Faculty of Management. He graduated from the Faculty of Commercial and Business Sciences in Celje, he received his Master degree at the Faculty of Management of the University of Primorska. He is employed at Ljubljanski potniški promet in Ljubljana. His research interests include the field of management, healthy lifestyle and professional drivers, because he himself performed the work of a professional driver. He has already published some scientific articles on this subject. The author can be contacted at anrejjerman1@gmail.com.

Ivan Erenda, Ph.D. is Director - Member of Management at TPV. He received PhD in Quality Management at the Faculty of Organisation Studies Novo mesto with the dissertation thesis "Leadership Competencies and Intuitive Decision Making of Top and Middle Management in the Automotive Industry". In terms of research, he mainly deals with competencies of intuitive performance, crisis management and smart factories. The author can be contacted at i.erenda@tpv.si.

Andrej Bertoncelj, Ph.D. is Professor of Management at the Faculty of Management, University of Primorska. He has extensive international experience in general management with particular focus on M\&A and strategic alliances. His scientific papers were published in many international journals and his book on mergers and acquisitions is translated in three foreign languages. His research interests include growth strategy, globalisation trends, mergers, acquisitions, and post-merger integration. He received a silver award of recognition from Slovene Chamber of Commerce for co-development of the business model of four evolutionary phases. The author can be contacted at andrej.bertoncelj@fm-kp.si. 